\title{
Studiemateriaal \\ Discipline celbiologie/histologie
}

\author{
J.P.M. Schellens, A.L. Bootsma, V. Everts, C. Terleth
}

\section{Besproken studiemateriaal}

1. Essential Cell Biology. B. Alberts et al.

2. Molecular Biology of the Cell. B. Alberts et al.

3. The Cell, a molecular approach. G.M. Cooper.

4. Functionele Histologie. L.C. Junqueira/E. Wisse et al.

5. Human Histology. A. Stevens en J. Lowe.

6. Histology, a text and atlas. M.H. Ross et al.

7. Wheather's Functional Histology. B. Young, J.W. Heath.

8. Color textbook of Histology. L.P. Gartner, J.L. Hiatt.

9. Essential Histology. D.H. Cormack.

Clinically Integrated Histology. D.H. Cormack.

10. Basic Medical Histology. R.G. Kessel.

11. Human Anatomy \& Physiology. E.N. Marieb.

\section{Inleiding}

De ontwikkeling die de celbiologie/histologie in de laatste decennia heeft doorgemaakt, alsook de veranderingen in onderwijsmethoden zijn duidelijk terug te vinden in de leerboeken.

De celbiologie is zodanig in omvang toegenomen dat alle faculteiten hiervoor nu een afzonderlijk leerboek gebruiken. De samenhang tussen structuur en functie als centraal thema van het onderwijs in de celbiologie en histologie heeft ertoe geleid dat in de leerboeken de relatie met verwante vakgebieden duidelijk naar voren treedt. Dit geldt voor de fysiologie en pathologie en wat de celbiologie betreft, met name voor de biochemie.

In alle faculteiten wordt vanuit de discipline celbiologie/histologie ook een bijdrage geleverd aan het onderwijs in de immunologie. De positie die dit vakgebied inneemt, blijkt nogal verschillend en bovendien zijn bij het onderwijs in de immunologie experts vanuit meerdere disciplines betrokken. Hierbij wordt gebruik gemaakt van een groot aantal leerboeken, waarvan de bespreking naar ons oordeel buiten het bestek van dit overzicht valt.

Zeker in de nieuwe curricula wordt van de student meer en meer verwacht dat hij/zij zich een deel van de studiestof zelfstandig eigen maakt door zelfstudie. In de leerboeken vindt men deze ontwikkeling terug door een toenemende aandacht voor vragen en opdrachten en toevoeging van cd-roms. Het is te hopen dat bij deze studiemiddelen in de nabije toekomst minder nadruk wordt gelegd op cognitieve aspecten en meer aansluiting wordt gezocht bij probleemgestuurd onderwijs.

\section{Beknopte bespreking}

1. B. Alberts, D. Bray, A. Johnson, J. LeWis, M. RaFF, K. Roberts en P. WaLter. ESSENTIAL CELL Biology. AN INTRODUCTION TO THE MOLECULAR BIOLOGY OF THE CELL. NEW YorK: GaRLAND PUbLISHING CY; 1998.

Dit leerboek is uitermate geschikt om de student geneeskunde een concept mee te geven van de cel als bouwsteen van het (menselijk) lichaam. Het is daarentegen voor medisch biologen en medisch biochemici - zeker na de propedeuse - niet diepgaand genoeg.

Het boek is heel goed te gebruiken bij een geïntegreerde aanpak van het onderwijs in de celbiologie vanuit meerdere disciplines. Niettemin zullen biochemie, (antropo)genetica 
en fysiologie in meerdere of mindere mate behoefte hebben aan specifieke aanvulling.

Alle onderwerpen worden op een evenwichtige wijze behandeld en de tekst is gemakkelijk te begrijpen, ook voor een geneeskundestudent wiens voorkeur niet direct uitgaat naar de wijze waarop fundamentele vragen omtrent gezondheid en ziekte in een vakgebied als de celbiologie worden behandeld. De illustraties zijn perfect, de vragen die gesteld worden in de marge van de bladzijden met tekst en verder aan het einde van ieder hoofdstuk zijn uiterst relevant, evenals de samenvattingen per hoofdstuk in de vorm van "Essential Concepts".

De Glossary en Index zijn uitstekend verzorgd. De bijbehorende cd-rom blijft in kwaliteit wat achter bij het leerboek, dat kan worden beschouwd als het ideale studieboek celbiologie voor studenten geneeskunde.

2. B. ALBERTS, D. BRAY, J. LEWIS, M. RAFF, K. ROBERTS en J.D. Watson. Molecular Biology of the Cell. 3E DRUK, NeW YoRK: GaRLand PUblishing CY; 1994.

De laatste editie van dit topboek in de celbiologie stamt helaas uit 1994. Gelukkig is voor het voorjaar 2002 een nieuwe druk aangekondigd, want in principe is deze 'bijbel' het ideale boek voor een studie van de celbiologie. In de druk die nu nog wordt gebruikt, ontbreken jammer genoeg voorbeelden/casus, studieopdrachten en vragen. Overigens niets dan lof voor dit excellente studieboek dat tevens dient als referentiekader tijdens en na de studie. Alle onderwerpen komen op evenwichtige wijze glashelder aan bod. De tekst is uiterst gemakkelijk te lezen en de illustraties zijn uitstekend.

Dit boek is geschikt als studieboek voor studenten medische biologie en medische biochemie, maar niet voor studenten geneeskunde, aangezien het voor hen te diepgaand is.

3. G.M. Cooper. The Cell. A Molecular Approach. 2E DRUK, WASHINGTON DC: ASM PRESS; 2000.

Dit boek is typisch gericht op de Amerikaanse pre-med opleidingen. Het is goed en vlot geschreven, en voorzien van mooie figuren, die overigens niet alle even verhelderend zijn. Ieder hoofdstuk is voorzien van een verhandeling over een "key experiment" en een toepassing in "molecular medicine" en wordt afgesloten met een prima samenvatting, gekoppeld aan sleutelwoorden. Tevens staan daar vragen, die over het algemeen cognitief van aard zijn en (dus) niet erg spannend.

De benadering van onderwerpen is, zoals de titel aangeeft, moleculair. Ruwweg zijn er drie hoofdonderwerpen: "The flow of genetic information", "Cell structure and function" en "Cell regulation" met een apart hoofdstuk over kanker. Helaas ontbreekt een aantal voor de hand liggende onderwerpen. Met name de posttranslationele celbiologie komt er daardoor bekaaid af.

Het boek is door zijn opzet niet geschikt voor de artsopleiding en zal ook in een curriculum medische biologie als algemeen leerboek celbiologie niet goed bruikbaar zijn. Aan de Nederlandse universiteiten lijkt het met name geschikt voor a $(\mathrm{g})$ io's die tijdens hun onderzoek in celbiologisch vaarwater terecht zijn gekomen.

Bij het boek wordt een cd-rom geleverd, waarvan de tweede uitgave door toevoeging van interactieve onderdelen duidelijk aan kwaliteit heeft gewonnen.

\section{E. Wisse, P. NieuWenhuis en L. Ginsel. FUNCTIONELE Histologie. 8E DRUK, MAARSSEN: ELSEVIER; 2000.}

Bewerking van: L.C. Junqueira, J. Carneiro en R.O. Kelley. Basic Histology. 9e druk, Appleton en Lange; 1998. De 8e druk van de Nederlandse bewerking van 'Junqueira' is opvallend gewijzigd ten opzichte van de vorige edities en daardoor ook gemoderniseerd en verbeterd. De tekst benadrukt de relatie tussen vorm en functie, is over het algemeen helder geschreven en bevat geen overbodige details. Niettemin zal de student hier en daar met een vraagteken blijven zitten, bijvoorbeeld bij de combinatie van informatie over hetzelfde onderwerp in verschillende hoofdstukken.

Een belangrijk pluspunt vormt de ruime aandacht die wordt geschonken aan de correlatie met klinische gegevens. Ook nieuw is de toevoeging van een samenvatting per hoofdstuk, een prijzenswaardig idee dat -bezien als hulp voor de student bij tentamenstudie- in zijn uitwerking nog niet zo geslaagd is. Wellicht dat in het kader van zelfstudie ook het opnemen van studieopdrachten van oplopende moeilijkheidsgraad te overwegen is.

De illustraties hebben weinig verandering ondergaan en dat stelt teleur. De lichtmicroscopische foto's zijn alle nog in zwart/wit uitgevoerd. Zowel licht- als elektronenmicroscopi- 
sche afbeeldingen missen vaak helderheid, contrast en detaillering. Het is te hopen dat in dezen bij de volgende druk een inhaalslag kan worden uitgevoerd, waardoor de kwaliteit van de illustraties die van de tekst evenaart.

\section{A. Stevens en J. Lowe. Human Histology. 2e DRUK, LONDON: MOSBY; 1997.}

Dit is een histologieboek dat qua opzet verouderd aandoet. Het is erg beschrijvend en de functionele aspecten komen onvoldoende aan de orde. Een aantrekkelijk element van het boek zijn de aparte, goed herkenbare kaders waarin relaties met ziektebeelden worden aangegeven. Tevens worden na elk hoofdstuk enige vragen voorgelegd die het bestuderen van de stof enigszins kunnen vergemakkelijken. De tekst is vrij summier en de informatie is soms iets te compact weergegeven. De illustraties zijn van een redelijke kwaliteit, alhoewel de lichtmicroscopische foto's veelal moeilijk te interpreteren zijn. De diagrammen en tekeningen werken verhelderend. De hoeveelheid stof die behandeld wordt, is voldoende voor studenten geneeskunde.

Van dit werk is in 1997 bij Bohn Stafleu Van Loghum een Nederlandse vertaling verschenen. Helaas bevat deze uitgave zoveel fouten dat zij niet kan gelden als alternatief voor de Engelse editie.

\section{M.H. RosS, L.J. ROMWELL EN G.I. KAY. HISTOLOGY, A TEXT AND ATLAS. 3E DRUK, BALTIMORE: WILLIAMS \& WILKINS; 1995.}

Leerboek en atlas zijn bedoeld om in combinatie te worden gebruikt, maar kunnen ook afzonderlijk worden bestudeerd. Aan het einde van ieder hoofdstuk staan de betreffende pagina's van de atlas. Deze omvat in totaal 260 pagina's, waarvan foto's en begeleidende tekst ieder de helft innemen. De illustraties in leerboek en atlas zijn zonder uitzondering van hoge kwaliteit.

De tekst is uitgebreid, maar het woordgebruik is nogal complex. De lay-out is geen ideale leidraad voor het onderscheid van hoofd- en bijzaken. In de praktijk is gebleken dat met name jongerejaars studenten nogal moeite hebben met de tekst. Omdat het boek ook geen opdrachten en vragen bevat, is het nauwelijks geschikt voor zelfstudie.

De histologie wordt gepresenteerd in relatie met andere vakgebieden, hetgeen vooral tot ui- ting komt bij de onderwerpen die in een afzonderlijk kader nader worden toegelicht. Ten aanzien van een meer of minder gedetailleerde behandeling van onderwerpen zijn andere keuzen te verdedigen, maar het leerboek als geheel is van een zodanige kwaliteit dat het ook na de studie met succes geraadpleegd kan worden.

7. B. YounG, J.W. Heath. Wheater's Functional Histology. 4E DRUK, EDINBURGH: CHURCHILL LIVINGSTONE; 2000.

Bij deze nieuwe editie van "Functional Histology" is rekening gehouden met gebruik in geïntegreerd en probleemgestuurd medisch onderwijs. De auteurs beogen daarbij te voldoen aan de behoefte van studenten aan beknopte en overzichtelijke informatie. Zij zijn erin geslaagd om in relatief kort bestek veel informatie te verwerken, terwijl de tekst toch goed leesbaar blijft.

Het boek is zeer overzichtelijk en visueel aantrekkelijk. Gekozen is voor een indeling in drie onderdelen: "Cell", "Basic Tissue Types" en "Organ Systems". De hoofdstukken binnen deze onderdelen hebben een vaste structuur. $\mathrm{Na}$ een veelal korte algemene introductie volgt een uitwerking in de vorm van foto's, tekeningen en diagrammen, die alle voorzien zijn van een heldere verklarende tekst, waarin moderne celbiologische inzichten didactisch goed zijn verwerkt. De keuze en kwaliteit van de foto's en illustraties is uitmuntend. Alle lichtmicroscopische foto's en ook de getekende illustraties zijn in kleur uitgevoerd, waardoor het boek een 'feest voor het oog' is. De bijbehorende cd-rom omvat alle foto's en kan ten behoeve van presentaties worden aangevuld met eigen materiaal.

De opzet als atlas brengt wèl met zich mee dat de histologie als een op zichzelf staande discipline wordt gepresenteerd, waardoor de relatie met andere vakgebieden, inclusief de kliniek, buiten beeld blijft.

\section{L.P. Gartner en G.L. Hiatt. Color TeXtbook of Histology. 2E DRUK, Philadelphia: W.B. SAUNders COMPANY; 2001.}

De tekst van dit leerboek is duidelijk en compleet zodat het boek ook de (co-)assistent van nut kan zijn. De jongerejaars student zal soms meer informatie krijgen dan hij in deze fase van zijn studie nodig heeft.

Het boek is rijk geillustreerd, maar de weergave van foto's is kwalitatief minder dan in de 
eerste druk. De elektronenmicroscopische foto's zijn minder contrastrijk en vaak van een lagere vergroting dan wenselijk. Het gebruik van (driedimensionale) tekeningen is een belangrijk pluspunt, ook al zijn niet alle tekeningen duidelijk en is het kleurgebruik visueel weinig aantrekkelijk. Gelukkig zijn niet alleen structuren, maar ook processen in schema weergegeven. De relatie van de behandelde stof met klinische gegevens wordt regelmatig en duidelijk toegelicht.

Gegevens over gebruik van het boek voor zelfstudie bij Nederlandse universiteiten zijn niet beschikbaar. De integratie van structurele en functionele gegevens wordt wellicht iets te veel aan de student overgelaten. Soms zou voor dit doel een eenvoudige herschikking of beperking van de tekst te overwegen zijn. Het grote aantal overzichtstabellen biedt in dezen onvoldoende soulaas: zij bieden vaak zoveel informatie dat zij althans voor tentamenstudie minder geschikt zijn.

9. D.H. Cormack. Essential Histology. 2E DRUK, PHILADELPHIA: LIPPINCOTT WILLIAMS \& WILKINS; 2001.

In dit boek ligt de nadruk op een beknopte, maar gedegen behandeling van de functioneelmorfologische aspecten van weefsels en organen. De tekst bevat ook aardige verwijzingen naar klinisch relevante voorbeelden. Zeer onlangs is een nieuwe druk verschenen. Het boek is niet wezenlijk veranderd qua opzet, inhoud en illustraties, maar de tekst is duidelijk in zijn geheel onder de loep genomen.

Didactisch gezien is het boek goed opgezet. Ieder hoofdstuk begint met een aantal leerdoelen. Deze zijn vervolgens uitgewerkt in heldere paragrafen. De illustraties en foto's bij de teksten in de paragrafen zijn prima gekozen en verhelderen de tekst. Wel is het jammer dat kleurenfoto's hierbij ontbreken. Dit laatste wordt enigszins gecompenseerd door een klein atlasje met kleurenfoto's middenin het boek; overigens betreft dit vrijwel uitsluitend HE preparaten.

Ondanks de beperkingen, is het boek zeer geschikt voor gebruik in cursussen histologie en microscopische anatomie. Voor gebruik als naslagwerk in latere fasen van de studie is de beknoptheid een nadeel. Helaas is het boek veel minder geschikt gebleken in geïntegreerd en probleemgestuurd onderwijs, waarbij studenten - in tijd versnipperd - op efficiënte wijze re- levante deelinformatie uit leerboeken moeten halen.

Van dezelfde auteur is in 1998 "Clinically Integrated Histology" verschenen, waarin voor alle orgaansystemen de histologische aspecten van een aantal pathologiecasus worden uitgewerkt. Na presentatie van de casus met een aantal vragen volgt behandeling van de relevante normale histologie, op basis waarvan de casus daarna worden besproken. (Hinderlijk is dat bij de kruisreferenties wordt verwezen naar de inmiddels uitverkochte 1e druk van "Essential Histology"). Dit boek is niet geschikt en ook niet bedoeld om een leerboek histologie te vervangen, maar is wèl geschikt voor "problem based learning". De behandeling van de normale histologie van de orgaansystemen is voor het beoogde doel wel erg uitvoerig, maar omvat anderzijds interessante dwarsverbindingen met andere vakgebieden (pathologie, fysiologie, biochemie) en - naast illustraties uit de 1e druk van het leerboek - nieuwe afbeeldingen en foto's. Zowel de relatie met andere vakgebieden, als de nieuwe illustraties zou men graag in de recente druk van "Essential Histology" hebben teruggevonden. Jammer dat de auteur deze kans heeft laten liggen.

\section{R.G. Kessel. Basic Medical Histology. NeW YOIRK: OXFORD UNIVERSITY PRESS; 1998.}

De presentatie van de histologie in dit leerboek is klassiek en biedt daarbij ook een correlatie met klinische gegevens. De tekst laat zich niet altijd gemakkelijk lezen. Dit wordt ten dele gecompenseerd door een groot aantal tabellen en vele schematische tekeningen. Naast enkele lacunes en onduidelijkheden treft men ook overbodige details.

De presentatie van het fotomateriaal stelt teleur. De indruk ontstaat dat vele briljante foto's bij het reproduceren aan kwaliteit hebben ingeboet. Het aantal SEM foto's is wel erg groot. Jammer genoeg zijn in de hoofdstukken geen foto's van lichtmicroscopische preparaten te vinden. Deze zijn samengebracht in een kleurenatlas in het midden van het boek. Bovendien zijn tekst en afbeeldingen in de hoofdstukken niet zorgvuldig genoeg gecorreleerd, waardoor hinderlijk bladerwerk nodig is.

Uit de (getekende) samenvatting van structuur en functie van de eukaryote cel, de verklarende woordenlijst en een aantal verrassend originele diagrammen blijkt dat weliswaar rekening is gehouden met gebruik van het boek 
voor zelfstudie, maar dit zou bij een volgende druk meer aandacht verdienen.

\section{E.N. Marieb. Human ANATOMY \& Physiology. 5E DRUK, SAN FRANCISCO: ADDISON, WESLEY, LONGMAN INC; 2001.}

Dit boek geeft een uitstekend overzicht van de humane fysiologie en anatomie, binnen welk kader ook de relevante celbiologie en histologie wordt besproken. Het aantrekkelijke van het boek is dat de verschillende onderwerpen duidelijk en met een goede samenhang worden behandeld. De tekst is helder, de figuren zijn van een goede kwaliteit en de veel voorkomende diagrammen zijn zeer verhelderend. Het regelmatig aangeven van de medische relevantie maakt het boek uiterst bruikbaar voor medisch gerichte opleidingen. Aangezien er gekozen is voor het onderbrengen van een zeer groot aantal onderwerpen binnen één en hetzelfde boek, mist het echte diepgang. Mede hierdoor zal het gebruik van dit boek voor studenten geneeskunde beperkt zijn. Het is uiterst geschikt voor studenten van universitaire opleidingen waarbij het biomedisch element niet de boventoon voert. Daarnaast is het een uitstekend boek voor biomedische beroepsopleidingen. Het is voor geïntegreerde bestudering van anatomie, fysiologie en celbiologie/histologie, uiterst geschikt voor studenten van universitaire opleidingen waarbij het biomedisch element niet de boventoon voert.

De bijbehorende cd-rom is interactief. Vooral de behandelde casus zijn instructief vanwege de toegevoegde feedback.

\section{De auteurs:}

Dr. J.P.M. Schellens, Afdeling Celbiologie en Histologie, Academisch Medisch Centrum, Amsterdam.

Mevr. dr. A.L. Bootsma, Afdeling Celbiologie, Universitair Medisch Centrum Utrecht.

Dr. V. Everts, Afdeling Celbiologie en Histologie, Academisch Medisch Centrum, Amsterdam.

Dr. C. Terleth, Afdeling Moleculaire Celbiologie, Leiden Universitair Medisch Centrum.

De auteurs danken prof. dr. C.J.F. van Noorden voor deskundig advies en kritisch commentaar.

\section{Correspondentieadres:}

Dr. J.P.M. Schellens, Afdeling Celbiologie en Histologie, Academisch Medisch Centrum, Meibergdreef 15, 1105 AZ Amstrdam,fax.020-697 4156, j.p.schellens@amc.uva.nl. 


\begin{tabular}{|c|c|c|c|c|c|c|c|c|c|c|c|}
\hline Beoordeelde kenmerken ${ }^{1}$ & 1 & 2 & 3 & 4 & 5 & 6 & 7 & 8 & 9 & 10 & 11 \\
\hline Relevantie voor artsopleiding & 5 & 3 & 3 & 4 & 3 & 4 & 4 & 4 & 4 & 4 & 3 \\
\hline Relevantie voor medische biologie/ & & & & & & & & & & & \\
\hline gezondheidswetenschappen & 3 & 5 & 4 & 4 & 3 & 4 & 4 & 3 & 4 & 3 & 3 \\
\hline Inhoudelijke kwaliteit & 5 & 5 & 5 & 4 & 3 & 3 & 4 & 4 & 4 & 3 & 4 \\
\hline Vormgeving & 5 & 4 & 4 & 3 & 3 & 4 & 5 & 3 & 3 & 2 & 5 \\
\hline Didactische kwaliteit & & & & & & & & & & & \\
\hline ('studeerbaarheid') & 5 & 5 & 4 & 4 & 3 & 3 & 4 & 4 & 4 & 3 & 4 \\
\hline Geschikt als verplichte zelfstudiestof & 5 & 5 & 4 & 4 & 3 & 2 & 4 & 3 & 3 & 2 & 5 \\
\hline Kwaliteit verwijssystematiek & & & & & & & & & & & \\
\hline en dekking van materie & 3 & 3 & 3 & 3 & 3 & 4 & 3 & 4 & 3 & 3 & 4 \\
\hline Geschiktheid voor gehele studie & 5 & 5 & 3 & 4 & 3 & 3 & 3 & 4 & 3 & 3 & 3 \\
\hline Kwaliteit voorbeelden/casus & - & - & 4 & 4 & 3 & 4 & - & 4 & 4 & 3 & 3 \\
\hline $\begin{array}{l}\text { Kwaliteit studieopdrachten } \\
\text { of vragen }\end{array}$ & 5 & - & 3 & - & 3 & - & - & - & - & - & 4 \\
\hline Kwaliteit antwoorden bij & & & & & & & & & & & \\
\hline studieopgaven of vragen & 5 & - & 4 & - & 4 & - & - & - & - & - & 4 \\
\hline \multicolumn{12}{|l|}{ Beschrijvende kenmerken } \\
\hline Taal & $\mathrm{E}$ & $\mathrm{E}$ & $\mathrm{E}$ & $\mathrm{N}$ & $\mathrm{E}$ & $\mathrm{E}$ & $\mathrm{E}$ & $\mathrm{E}$ & $\mathrm{E}$ & $\mathrm{E}$ & $\mathrm{E}$ \\
\hline Omvang in pagina's & 630 & 1294 & 689 & 576 & 408 & 823 & 413 & 577 & 463 & 550 & 1249 \\
\hline $\begin{array}{l}\text { Omvang (breedte } \mathrm{x} \text { hoogte, } \\
\text { afgerond in } \mathrm{cm} \text { ) }\end{array}$ & $22 \times 28$ & $22 \times 28$ & $22 \times 28$ & $19 \times 26$ & $22 \times 28$ & $22 \times 28$ & $21 \times 30$ & $20 \times 25$ & $18 \times 25$ & $22 \times 28$ & $22 \times 28$ \\
\hline Aantal delen & 1 & 1 & 1 & 1 & 1 & 1 & 1 & 1 & 1 & 1 & 1 \\
\hline Druk & 1 & 3 & & 2 & 8 & 2 & 3 & 4 & 2 & 2 & 15 \\
\hline Jaar van uitgave & 1998 & 1994 & 2000 & 2000 & 1997 & 1995 & 2000 & 2001 & 2001 & 1998 & 2001 \\
\hline Jaar van eerste druk & 1998 & 1983 & 1997 & 1981 & & 1985 & 1979 & $\mid 1997$ & 1993 & 1998 & \\
\hline Prijs (in guldens) & 123 & 183 & 126 & 99 & 110 & 134 & 145 & 145 & 132 & 163 & 163 \\
\hline Prijs (in euro's) & 56 & 83 & 57 & 45 & 50 & 61 & 66 & 66 & 60 & 74 & 74 \\
\hline
\end{tabular}

${ }^{1}$ Beoordeling: 1=zeer slecht/zeer gering/zeer ongeschikt; $2=$ slecht/gering/ongeschikt; 3=matig 4=goed/groot/geschikt; $5=$ =eer goed/zeer groot/zeer geschikt; -=niet van toepassing. 